\title{
Synthesis and Application of FeCu Bimetallic Nanoparticles in Coal Mine Wastewater Treatment
}

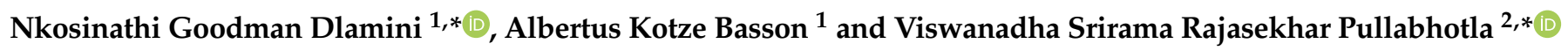 \\ 1 Department of Biochemistry and Microbiology, University of Zululand, Private Bag X1001, \\ KwaDlangezwa 3886, South Africa; BassonA@unizulu.ac.za \\ 2 Department of Chemistry, University of Zululand, Private Bag X1001, KwaDlangezwa 3886, South Africa \\ * Correspondence: nathidlamini03@gmail.com (N.G.D.); PullabhotlaV@unizulu.ac.za (V.S.R.P.); \\ Tel.: +27-35-902-6155 (V.S.R.P.)
}

check for

updates

Citation: Dlamini, N.G.; Basson, A.K.; Pullabhotla, V.S.R. Synthesis and Application of FeCu Bimetallic Nanoparticles in Coal Mine

Wastewater Treatment. Minerals 2021, 11, 132. https://doi.org/10.3390/ $\min 11020132$

Received: 16 December 2020

Accepted: 20 January 2021

Published: 28 January 2021

Publisher's Note: MDPI stays neutral with regard to jurisdictional claims in published maps and institutional affiliations.

Copyright: (C) 2021 by the authors. Licensee MDPI, Basel, Switzerland. This article is an open access article distributed under the terms and conditions of the Creative Commons Attribution (CC BY) license (https:// creativecommons.org/licenses/by/ $4.0 /)$.

\begin{abstract}
Wastewater treatment has become a global challenge with wastewater treatment cost fast increasing. Industrial processes such as downstream processes, wastewater treatment, and several fermentation processes depend largely on the use of flocculants. Synthetic flocculants, which are conventionally used in wastewater treatment, are hazardous to the environment and are carcinogenic to human health. Therefore, bioflocculants can be used as an alternative due to their biodegradable and environmentally friendly nature. However, low efficacy hinders their industrial application. This necessitates the need for a new technology to combat wastewater treatment challenges. Nanotechnology provides the platform to explore the possible solutions to these problems. The combination of two different metals results in the formation of bimetallic nanoparticles (BNPs). Due to better properties, bimetallic nanoparticles have attracted huge attention as compared to monometallic nanoparticles from both technological and scientific views. Iron copper bimetallic nanoparticles (FeCu BNPs) were successfully stabilized by bioflocculant and used in the coal mine wastewater treatment. Infrared spectrometric analysis showed the presence of carboxyl (COO-), hydroxyl $(-\mathrm{OH})$, and amino $\left(-\mathrm{NH}_{2}\right)$ functional groups. SEM images showed irregular and crystalline like morphology. Meanwhile, TEM analysis revealed chain like agglomerated nanoparticles. FeCu BNPs exhibited a wide $\mathrm{pH}$ stability range from 3, 7, and 11 with 99\% flocculation activity at $\mathrm{pH} 7$ and at lowest dosage of $0.2 \mathrm{mg} / \mathrm{mL}$. After treating wastewater, the FeCu BNPs could remove pollutants such as phosphate, sulfate, calcium, chemical oxygen demand (COD), and biological oxygen demand (BOD) with phosphate having the highest removal efficacy of $99 \%$.
\end{abstract}

Keywords: bimetallic nanoparticles; flocculation; pollutants; removal efficiency; wastewater

\section{Introduction}

The most common sources of environmental pollutants among others is waste discharge and industrial effluents. Generally, where coal mine activities are common, large amounts of wastewater are generated during coal processing resulting in water resource pollution. A vast number sulfide mineral such as pyrite ore $\left(\mathrm{FeS}_{2}\right)$ is exposed to water, air and microbes during mining and generate acid mine drainage (AMD) [1] and other pollutants such sulfur, phosphate, COD, and BOD [2]. Any water contaminated by organic pollutants, industrial effluent, bacteria, and microorganisms or any compound that deteriorate its initial quality is defined as wastewater and can be subdivided into domestic and industrial [1].

Chemical flocculants have been used extensively in pollutants removal in wastewater. This is due to their effectiveness at low dosages, long shelf life, and low cost [3]. Even though the chemical flocculants exhibit all these remarkable capabilities, in some developed countries these flocculants were banned due to the detrimental effect they possess to human, animals, and the environment [4]. The chemical flocculant shortcomings among others, include non-degradability and toxicity [5]. Recently, most emphasis is given to naturally 
occurring flocculants called "bioflocculants" as alternative agents to remove pollutants in wastewater, particularly biological oxygen demand, chemical oxygen demand, and sulfur. Bioflocculants are macromolecular polymers secreted by microorganisms during metabolic processes. They may be proteins, carbohydrates, nucleic acids or lipids [6]. In the removal of heavy metals, microalgae, and flocculating inorganic solid suspensions, bioflocculants have been effectively used $[7,8]$.

Due to their environmental friendliness and mostly nontoxic nature these bioflocculants have gained the attention of the researchers [6]. However, the natural flocculants are not as effective as the chemical flocculants; they are expensive to produce, have low efficacy, and low yield [9]. To improve the effectiveness of bioflocculants in wastewater treatment nanotechnology is viewed as a possible solution.

Most researchers have drawn their attention in recent years towards the nanotechnology. This new field of interest plays a vital role in many technological fields due to the predefined superstructures [10], these predefined structures come in different forms, such as monometallic, bimetallic, and trimetallic [11]. Trimetallic and bimetallic materials are of enormous interest than that of monometallic because of their properties can be tailored better and offer more surface area than that of single metallic [12]. Despite a weaker reduction ability, iron possesses many prominent advantages in water treatment application, including oxidation and precipitation (in the presence of dissolved oxygen), low cost, including excellent adsorption properties [13,14], while copper has been known to possess antimicrobial effects and has been used in wastewater treatment [15].

There are various techniques that can be used in the synthesis of bimetallic nanoparticle. El-Shall et al. [16] reported on a method which involves chemical reduction precursors under microwave irradiation. The objective of this study was to use a greener approach to synthesize $\mathrm{FeCu}$ bimetallic nanoparticles by a polysaccharide bioflocculant and evaluate its potential application on coal mine wastewater.

\section{Materials and Methods}

\subsection{Bioflocculant Production Media}

Sigma-Aldrich (St Louis, MO, USA) was used to procure all chemicals reagents and media used. The standard production medium prepared according to Zhang et al. [7] composed of glucose (20.0 g), $\mathrm{KH}_{2} \mathrm{PO}_{4}(2.0 \mathrm{~g}), \mathrm{K}_{2} \mathrm{HPO}_{4}(5.0 \mathrm{~g}),\left(\mathrm{NH}_{4}\right)_{2} \mathrm{SO}_{4}(0.2 \mathrm{~g}), \mathrm{NaCl}$ $(0.1 \mathrm{~g}), \mathrm{CH}_{4} \mathrm{~N}_{2} \mathrm{O}(0.5 \mathrm{~g}), \mathrm{MgSO}_{4}(0.2 \mathrm{~g})$, and yeast extract $(0.5 \mathrm{~g})$ in a liter of the filtered seawater. The media were autoclaved at $121^{\circ} \mathrm{C}$ for $15 \mathrm{~min}$.

\subsection{Source of Bacterium}

The organisms used for bioflocculant production was previously isolated from Sodwana Bay in KwaZulu Natal Province, South Africa. The organism was identified as Alcaligenes faecalis $H C B 2$ through $16 \mathrm{~s}$ rRNA and has been stored at $20 \%$ glycerol at $80{ }^{\circ} \mathrm{C}$ at the University of Zululand, Department of Biochemistry and Microbiology. Nutrient agar (NA) was used to revive the organism prior being used.

\subsection{Bioflocculant Extraction and Purification}

Prior to extraction, the organism was incubated at $30{ }^{\circ} \mathrm{C}$ in a shaker at $165 \mathrm{rpm}$ for $72 \mathrm{~h}$ using the above-described production media. Extraction and purification was conducted using the procedures described by Zhao et al. [17] with slight modification. One liter of production medium was prepared and sterilized using an autoclave. After $72 \mathrm{~h}$ of fermentation, the fermented broth was centrifuged at $8000 \mathrm{rpm}, 4^{\circ} \mathrm{C}$ for $30 \mathrm{~min}$ to remove bacterial cells. The supernatant was mixed with one volume of distilled water and centrifuged again at $8000 \mathrm{rpm}, 4^{\circ} \mathrm{C}$ for $15 \mathrm{~min}$ to remove insoluble substances. Two volumes of ethanol were added to the supernatant, stirred and left to stand at $4{ }^{\circ} \mathrm{C}$ overnight. The supernatant was discarded and the precipitate was vacuum-dried to obtain the crude biopolymer. The crude product was then dissolved in distilled water and mixed with one volume of chloroform/n-butyl alcohol (5:2 v/v). After stirring, the mixture was left 
to stand at room temperature for $12 \mathrm{~h}$. The upper phase was separated, centrifuged at $8000 \mathrm{rpm}$ for $15 \mathrm{~min}$ at $4{ }^{\circ} \mathrm{C}$ the supernatant was dialyzed against distilled water overnight. The dialysate was then vacuum-dried to obtain a purified bioflocculant.

\subsection{Synthesis of $\mathrm{FeCu}$ Bimetallic Nanoparticles}

To synthesize bimetallic nanoparticles, firstly monometallic nanoparticles were synthesized separately in accordance to a method described by Dlamini et al. [18] where $3.0 \mathrm{mM}$ iron sulfate and copper sulfate solutions were prepared using distilled water separately. Followed by $0.5 \mathrm{~g}$ of pure bioflocculant addition in both the solutions, agitated for 5-10 $\mathrm{min}$ in a shaking incubator at room temperature and left to stand for $24 \mathrm{~h}$ at room temperature. Formed precipitate was collected by centrifugation at $8000 \mathrm{rpm}, 4^{\circ} \mathrm{C}$, for $15 \mathrm{~min}$. Solutions of copper sulfate and iron sulfate were used as a control without the addition of bioflocculant. Physical observation and various characterization techniques were used to ascertain the formation of nanoparticles. After which, different volumes of FeNPs, 10, 20, and $30 \mathrm{~mL}$ was mixed successively with a solution of $\mathrm{CuSO}_{4}(0.003 \mathrm{M})$ in glucose $(6.0 \mathrm{~mL})$. Precipitates were collected through centrifugation at $15,000 \mathrm{rpm}$ at $4{ }^{\circ} \mathrm{C}$ for $30 \mathrm{~min}$ after the reaction was allowed to continue for $20 \mathrm{~min}$.

\subsection{Characterization of $\mathrm{FeCu}$ Nanoparticles}

A scanning electron microscope equipped with an elemental detector (SEM-SipmaVP-03-67) was used to detect the morphology and the elemental composition. While the functional groups present in the sample were verified and confirmed by Fourier Transform-Infrared (FT-IR) spectroscopy analysis (Tensor 27, Bruker FT-IR spectrophotometer, Gauteng, South Africa). A transmission electron microscope (JEOL USA, Inc., Peabody, MA 01960, USA) was used to obtain images of the nanoparticles. Micropipettes were used to prepare specimens, in which a diluted drop of suspension was placed on a formvar coated copper grid having 150 mesh size. The samples were left to completely dry at room temperature. Samples were viewed at $100 \mathrm{kV}$ as the accelerating voltage. The images were captured digitally using a Megaview III camera, stored and measured using Soft Imaging System iTEM software. A Bruker D8 Advance diffractometer (Bruker, Gauteng, South Africa) equipped with $\mathrm{Cu}-\mathrm{K} \alpha$ radiation $(\lambda=1.5406 \AA)$ was used to obtain diffractor patterns and the patterns were recorded at room temperature by placing dry powder of the sample on the sample holder, with $40 \mathrm{kV}$ and $40 \mathrm{~mA}$ operating conditions.

\subsection{Flocculation Activity Determination}

To determine the flocculating activity, a method was used in accordance with the method previously described by Kurane et al. [19] with minor modifications was used. A hundred $\mathrm{mL}$ of kaolin clay suspension $(4 \mathrm{~g} / \mathrm{L}), 3 \mathrm{~mL}$ of $1 \% \mathrm{CaCl}_{2}$ and $2.0 \mathrm{~mL}$ of $0.2 \mathrm{mg} / \mathrm{mL}$ of $\mathrm{FeCu}$ nanoparticles were added in a $250 \mathrm{~mL}$ flask. The mixture was shaken vigorously for $60 \mathrm{~s}$ and thereafter poured into a $100 \mathrm{~mL}$ measuring cylinder, which was then allowed to stand for $5 \mathrm{~min}$ at room temperature. A UV-Vis spectrophotometer was used to measure the optical density of the clarifying supernatant and control, which was, deionized water at $550 \mathrm{~nm}$. The optical density (OD) of the clarifying solution was measured in a spectrophotometer at $550 \mathrm{~nm}$. The flocculating activity was determined by using the following formula:

$$
\text { Flocculating activity }(\%)=\left[\frac{A-B}{A}\right] \times 100
$$

where $A$ and $B$ are the optical densities measured at $550 \mathrm{~nm}$ of the control and sample, respectively.

\subsection{Determination of Physico-Chemical Parameters in Wastewater Samples}

The wastewater samples were collected aseptically using autoclaved scotch bottles, preserved in ice, and were assessed promptly once they got into the lab. The sampling site 
is Tendele coal mine, which is located in the province of KwaZulu-Natal, South Africa, and the physico-chemical parameters are shown in Table 1.

Table 1. Summary of physicochemical characteristics $(\mathrm{mg} / \mathrm{L})$ in the coal mine wastewater.

\begin{tabular}{cccccccc}
\hline $\begin{array}{c}\text { Sample } \\
\text { Site }\end{array}$ & $\mathrm{pH}$ & $\begin{array}{c}\text { Absorbance } \\
(\mathbf{6 8 0} \mathbf{n m})\end{array}$ & $\begin{array}{c}\mathrm{PO}_{4}{ }^{3-} \\
(\mathbf{m g} / \mathrm{L})\end{array}$ & $\begin{array}{c}\mathrm{SO}_{4}{ }^{2-} \\
(\mathbf{m g} / \mathrm{L})\end{array}$ & $\begin{array}{c}\mathrm{Ca}^{2+} \\
(\mathbf{m g} / \mathrm{L})\end{array}$ & $\begin{array}{c}\mathrm{COD} \\
(\mathbf{m g} / \mathrm{L})\end{array}$ & $\begin{array}{c}\mathrm{BOD} \\
(\mathbf{m g} / \mathrm{L})\end{array}$ \\
\hline $\begin{array}{c}\text { Coal } \\
\text { mine }\end{array}$ & 8.2 & 2.9 & 2.0 & 55 & 132 & 1557 & 123.2 \\
\hline
\end{tabular}

\subsection{Removal of Pollutants in Wastewater by $\mathrm{FeCu}$ Nanoparticles}

Tendele coal mine wastewater samples were used during experimental modelling. The mine is located in KwaZulu Natal province, South Africa. Different pollutants, such as COD, $\mathrm{BOD}$, phosphate, sulfate, and calcium were evaluated using test kits. To measure COD, Supelco COD Cell Test, Merck was used following the manufacturer's protocol, and BOD was evaluated using Supelco BOD Cell Test, Merck. While the Supelco Phosphate Cell Test, Merck was used for phosphate in accordance with the protocol of the manufacturer. Lastly, sulfate and calcium were evaluated using Supelco Sulfate Cell Test, Merck, and Supelco Calcium Cell Test, Merck, respectively. Removal efficacy of pollutants was measured by UV-Vis Pharo 300 Spectroquant ${ }^{\circledR}$, Merck) at $680 \mathrm{~nm}$. The following equation was used to calculate removal efficiency $(R E)$ of the pollutants:

$$
R E(\%)=\frac{C i-C f}{C i} \times 100
$$

where $C_{i}$ is the initial value and $C_{f}$ is the value after the flocculation treatment.

\subsection{Statistical Analysis}

All experiments where done in triplicate and the standard deviation of the mean values was taken. The data were then subjected to a one-way analysis of variance (ANOVA) using Graph pad prism 6.1.A significant level of $p<0.05$ was used. Different letters show that measurements are statistically different whilst the same letter shows no significance.

\section{Results}

3.1. Fourier Transform-Infrared Spectroscopy Analysis of FeCu Nanoparticles

Functional groups such as hydroxyl and amine play a significant role in the flocculation capabilities of the synthesized nanoparticles (Figure 1).

\subsection{Transmission Electron Microscopy Analysis of FeCu Nanoparticles}

The TEM images are shown in Figure 2a bioflocculant and Figure $2 \mathrm{~b}$ FeCu nanoparticles. The nanoparticles are agglomerated and are smaller in size compared to a bioflocculant.

\subsection{Scanning Electron Microscopy Analysis of FeCu Nanoparticles}

Irregular and crystalline like morphology is shown in Figure 3 and elements such as oxygen and carbon were observed from the EDX spectra.

\subsection{X-Ray Diffraction Analysis of FeCu BPNs Nanoparticles}

X-ray diffraction patterns of FeCu BPNs nanoparticles are shown in Figure 4. Strong and characteristic crystalline peaks are observed between $30^{\circ}$ and $65^{\circ}$ at $2 \theta$. 


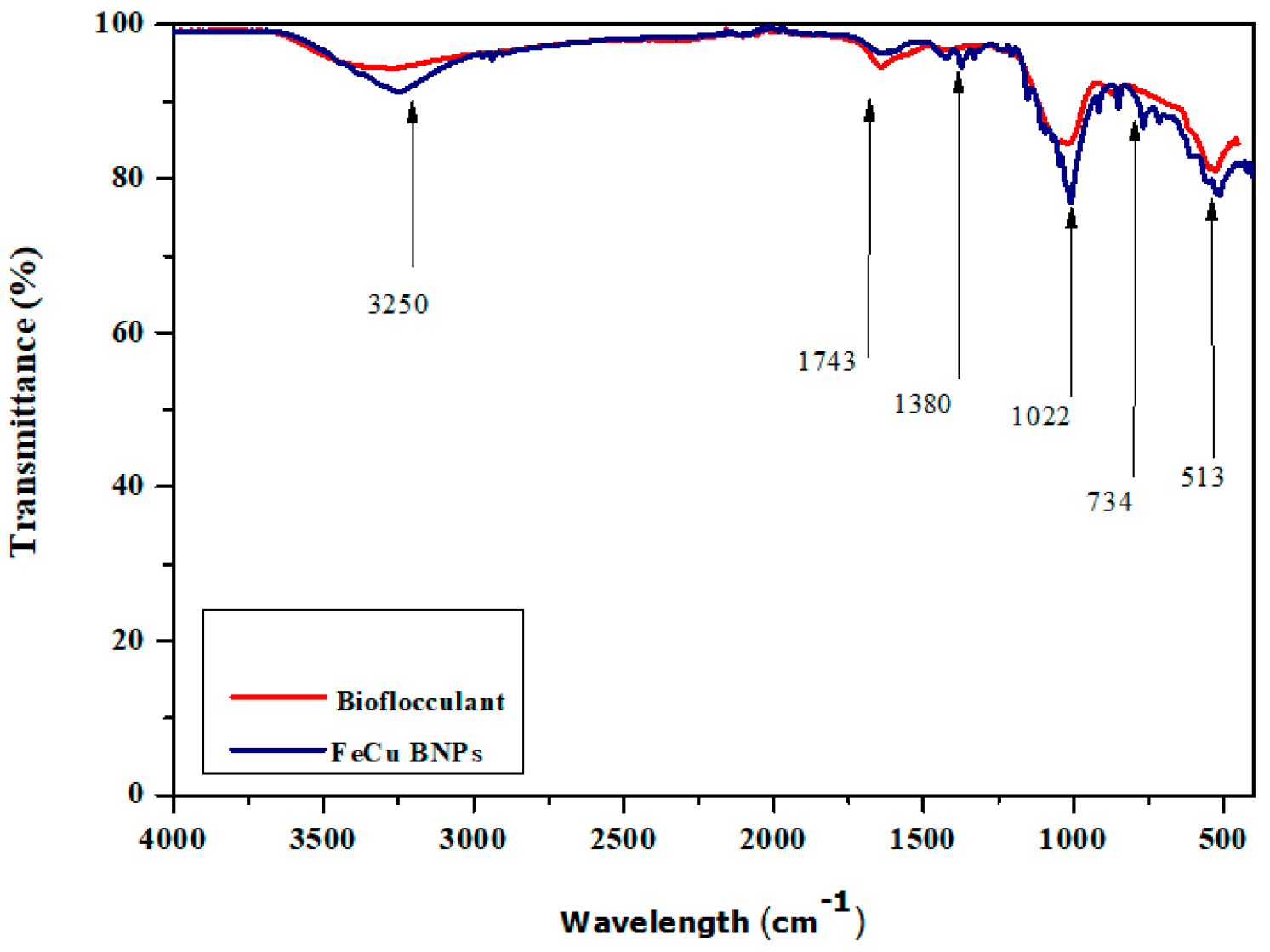

Figure 1. Fourier transform-infrared (FT-IR) spectrum of FeCu nanoparticles.

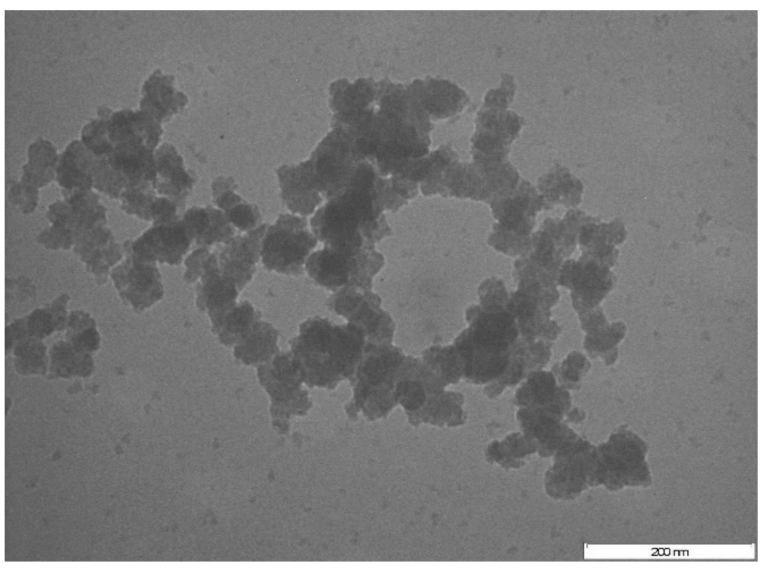

(a)

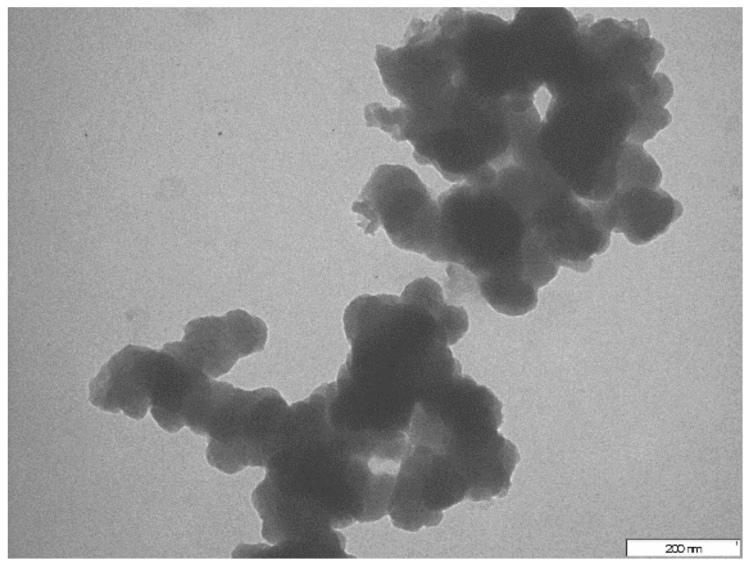

(b)

Figure 2. TEM images of (a) bioflocculant and (b) FeCu bimetallic nanoparticles (BNPs). 


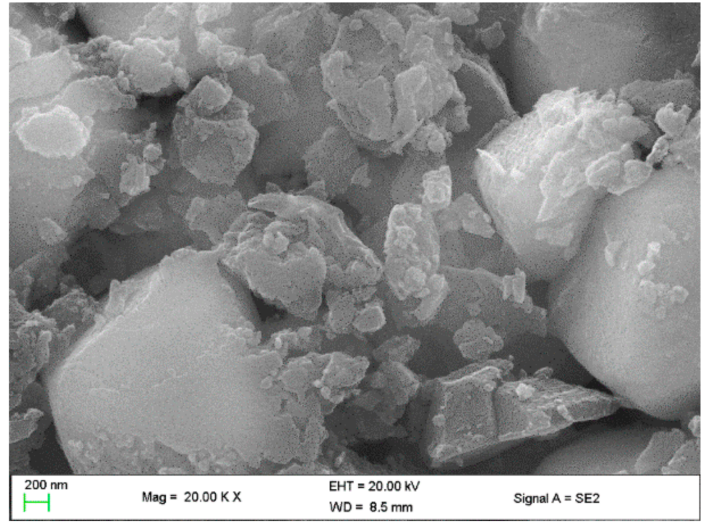

(a)

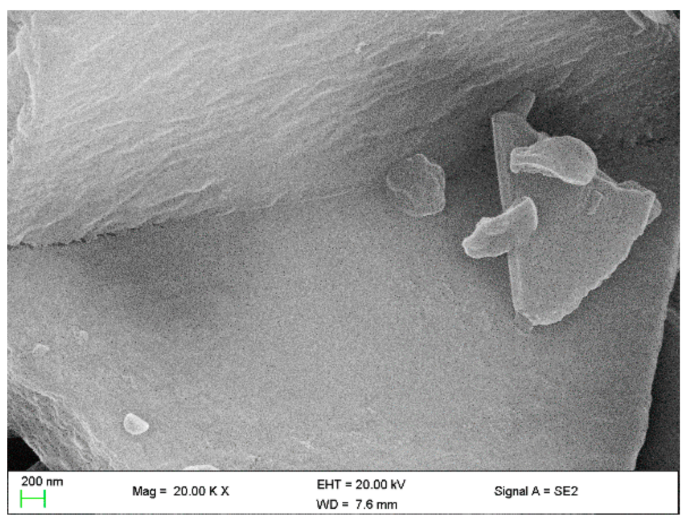

(c)

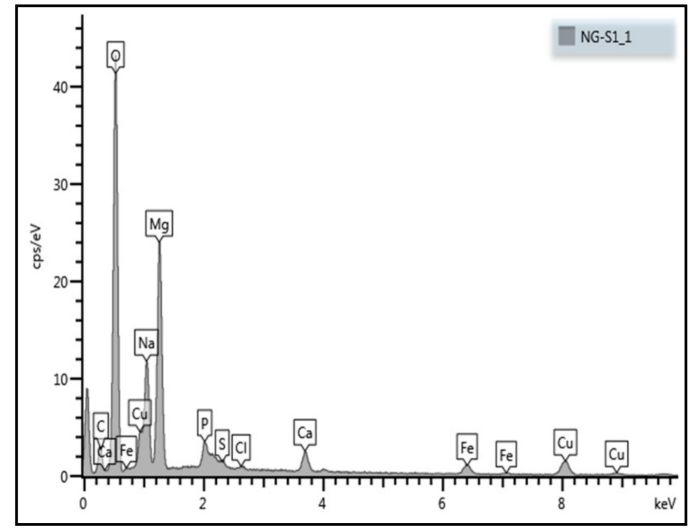

(b)

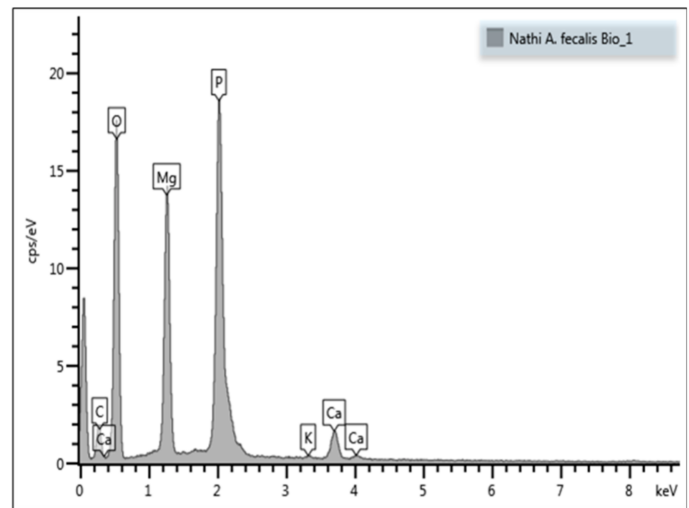

(d)

Figure 3. SEM images of (a) FeCu BNPs (b) corresponding Energy-Dispersive (EDS) spectrum (c) bioflocculant and (d) corresponding EDS spectrum.

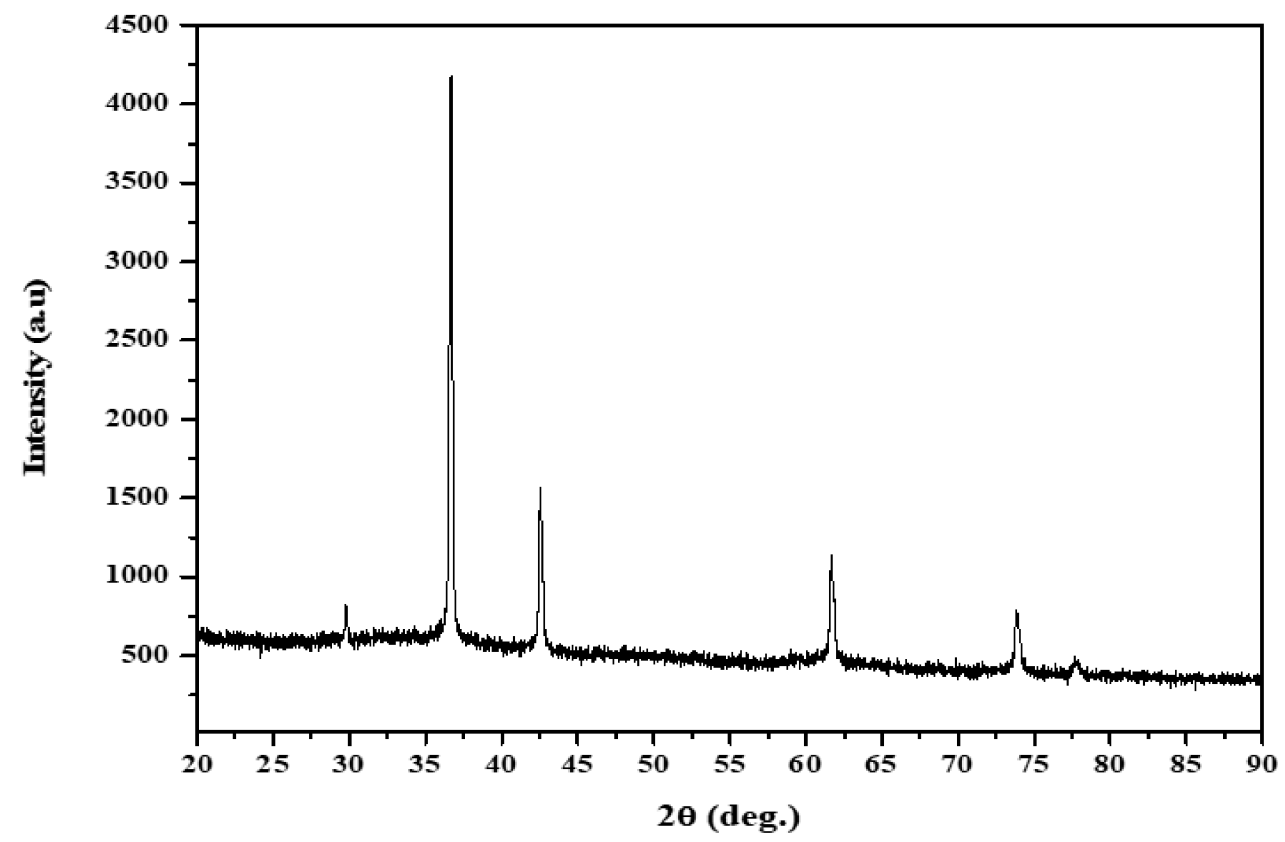

Figure 4. X-ray diffractogram of $\mathrm{FeCu}$ nanoparticles. 


\subsection{Effect of Nanoparticles Dosage on Flocculation of Kaolin and Coal Mine Wastewater}

For an optimal flocculation efficiency, $0.2 \mathrm{mg} / \mathrm{mL}$ dosage is required by the bimetallic iron-copper nanoparticles. The adequate dosage is required for the efficient flocculation process. The results showed that there is no statistical significance between $(0.2$ and $0.4 \mathrm{mg} / \mathrm{mL})$ dosages for flocculation activity. The least dosage $(0.2 \mathrm{mg} / \mathrm{mL})$ was chosen for all subsequent experiment (Figure 5).

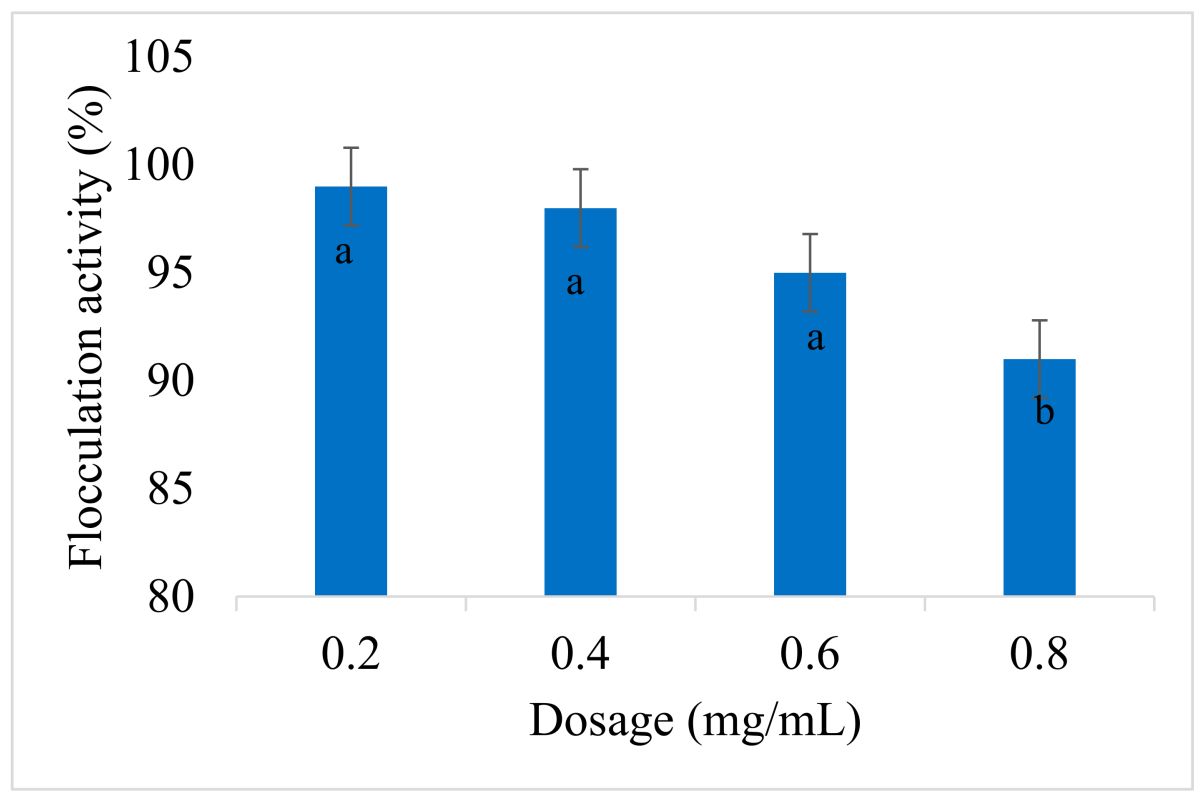

Figure 5. Effect of nanoparticles on flocculation activity. Different letters (a and b) denote statistical significance at $p<0.05$.

\subsection{Effect of Nanoparticles $p H$ on Flocculation of Kaolin and Coal Mine Wastewater}

The effect of $\mathrm{pH}$ on $\mathrm{FeCu}$ nanoparticles was investigated at $(3,7$, and 11) is shown in Figure 6. The results showed that the nanoparticles flocculate effectively on all three $\mathrm{pH}$ values investigated.

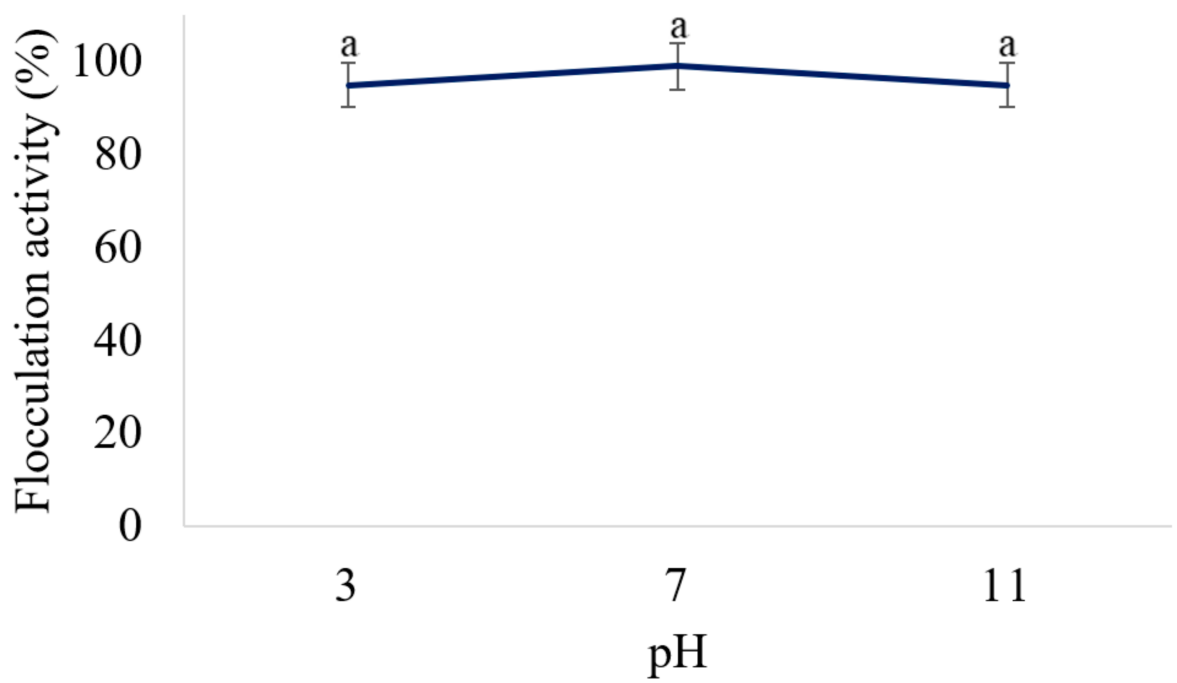

Figure 6. Effect of nanoparticle $\mathrm{pH}$ on flocculation activity. Letter (a) denotes statistical significance at $p<0.05$. 


\subsection{Flocculation Activity of Different Water Samples by FeCu Nanoparticles}

The $\mathrm{FeCu}$ nanoparticles have the highest flocculation activity on kaolin clay with $99 \%$ flocculation activity followed by the coal mine wastewater sample with $85 \%$.

\subsection{Physicochemical Parameters in Wastewater Samples}

The physicochemical properties of coal mine wastewater such as $\mathrm{pH}$, absorbance, phosphate, sulfate, calcium, COD, and BOD are summarized in Table 1.

\subsection{Pollutants Removal in Wastewater by $\mathrm{Fe} / \mathrm{Cu}$ Nanoparticles}

Table 2 shows the removal efficiency of pollutants from coal mine wastewater. $\mathrm{FeCu}$ BNPs showed high affinity for all pollutants with phosphate being the highest.

Table 2. Removal efficiency for pollutants from coal mine wastewater by FeCu BNPs at room temperature.

\begin{tabular}{ccccc}
\hline Flocculant & $\begin{array}{c}\text { Parameter } \\
(\mathbf{m g} / \mathbf{L})\end{array}$ & $\begin{array}{c}\text { Water Quality } \\
\text { before }(\mathbf{m g} / \mathbf{L})\end{array}$ & $\begin{array}{c}\text { Water Quality } \\
\text { after }(\mathbf{m g} / \mathbf{L})\end{array}$ & $\begin{array}{c}\text { Removal } \\
\text { Efficiency (\%) }\end{array}$ \\
\hline & Phosphate & $2.0 \pm 0.0$ & $0.04 \pm 0.0$ & 98 \\
FeCu BNPs & Calcium & $132 \pm 0.0$ & $8.16 \pm 0.0$ & 87 \\
& Sulfate & $55 \pm 0.1$ & $11.55 \pm 0.1$ & 79 \\
& COD & $1557 \pm 0.0$ & $124.56 \pm 0.0$ & 92 \\
& BOD & $123.2 \pm 0.0$ & $3.41 \pm 0.0$ & 97 \\
\hline
\end{tabular}

\section{Discussion}

Flocculant binding capability depends on the number of functional groups in their molecular chains [6]. FT-IR characterization was conducted for the possible binding sites for stabilization of $\mathrm{FeCu}$ by the bioflocculant. As shown in Figure 1, the strong bend appeared at $3250 \mathrm{~cm}^{-1}$ is characteristics of hydroxyl group $(-\mathrm{OH})$ and amine group $\left(-\mathrm{NH}_{2}\right)$. In addition, bands included asymmetrical stretching peak at $1743 \mathrm{~cm}^{-1}$ and symmetrical medium stretching peak at $1380 \mathrm{~cm}^{-1}$ indicating carboxyl group $(\mathrm{C}-\mathrm{O}-\mathrm{H})$. Meanwhile the methoxyl group is observed by of stretching C-O as indicated by a peak at $1022 \mathrm{~cm}^{-1}$. The peaks at $734-513 \mathrm{~cm}^{-1}$ suggest the presence of saccharide derivatives. The presence of $-\mathrm{COOH},-\mathrm{COO}^{-}$, and $-\mathrm{OH}$ groups on the as-synthesized nanoparticles and $\mathrm{H}^{+}$and $\mathrm{OH}^{-}$groups on the surface of colloidal particles may interact with the nanoparticle chains to form hydrogen bonds, which permit larger floc formation. The $-\mathrm{OH}$ group plays the significant role in stabilizing the synthesis material [20]. Compared to the bioflocculant, the IR characterization spectrum of the bioflocculant showed that several noticeable vibrational changes occurred in $\mathrm{FeCu}$. The results showed that $\mathrm{FeCu}$ nanoparticles were successfully stabilized by the bioflocculant, and $\mathrm{N}$ and $\mathrm{O}$ atoms are reactive sites responsible for the bonding [21].

The transmission electron micrographs of the bioflocculant and $\mathrm{FeCu}$ nanoparticles are shown in Figure 2. Aggregated bioflocculant particles can be found in Figure 2a. The $\mathrm{FeCu} \mathrm{BNPs}$ formed a chain-like aggregation attributed to the magnetic attractive force as shown in Figure 2b. The TEM images revealed that the nanoparticles are highly aggregated, which could be due to the magnetic property of those compounds [22]. Agglomeration may be attributed to the interaction of the electrons of the interconnected particles [23].

Morphological changes were observed using SEM analysis as shown in Figure 3a,c. As indicated in Figure 3a, bimetallic $\mathrm{FeCu}$ was composed of irregular particles, while Figure $3 \mathrm{c}$ showed a crystalline bioflocculant. This suggested that the bimetallic nanoparticles were formed as the bioflocculant was morphologically modified. Zhang et al. [11] stated that bioflocculant surface morphology plays a significant role in the flocculation process. Poor or effective flocculation activity may be accounted for the surface morphological structure of bioflocculants. EDX analysis is shown in Figure 3b,d, as indicated, elements such as $\mathrm{O}$ and $\mathrm{C}$ are present in abundance which is evident from both figures. This is because these elements form the structure of the bioflocculant, and a number of elements bring about the stability and flexibility of the bioflocculant. From Figure 3b, it can be noted that the 
presence of Fe and $\mathrm{Cu}$ in the sample which could not be found in Figure 3d. This further confirms the formation of nanoparticles by the bioflocculant. The other elements, $\mathrm{Mg}, \mathrm{Na}$, $\mathrm{Ca}$, and $\mathrm{K}$ form part of the bioflocculant production media that was used for production of the bioflocculant. X-ray diffraction patterns are shown in Figure 4. Strong peaks are observed at $2 \theta \sim 36^{\circ}, 45^{\circ}$, and $65^{\circ}$. Crystallinity and smaller particle size are normally represented by strong peaks.

Each flocculant flocculates maximally at the optimum dosage. Below this dosage, significant bridging cannot occur between flocculants and colloids [5]. Contrary to this, beyond optimal dosage size, flocculation activity declines due to flocs being destabilize by excess flocculant. Wang et al. [24] alluded that high viscosity may result from excessive amounts of flocculant concentrations, which in turn can lead to a reduction in the settling of flocculated colloidal particles. From Figure 5, flocculation activity efficacy of $\mathrm{FeCu}$ nanoparticles can be assessed in kaolin clay. The optimum flocculation activity was achieved at a $0.2 \mathrm{mg} / \mathrm{mL}$ dosage. The nanoparticles flocculate effectively at low dosage $(0.2 \mathrm{mg} / \mathrm{mL})$. However, with the increase in dosage, from 0.4 to $0.6 \mathrm{mg} / \mathrm{mL}$ the results indicate that any dosage can be used as there was no statistical significance. Although $0.2 \mathrm{mg} / \mathrm{mL}$ was the lowest concentration, it was chosen as the optimal for all subsequent experiments. Moreover, the use of relatively smaller dosages reduces wastewater treatment costs [25]. The concentration of $0.8 \mathrm{mg} / \mathrm{mL}$ may not permit flocculation to happen effectively as it can be seen from the significant drop from $99 \%$ at $0.2 \mathrm{mg} / \mathrm{mL}$ to $91 \%$ at the concentration of $0.8 \mathrm{mg} / \mathrm{mL}$. The findings are in agreement with those of Dlamini et al. [2], where they indicated that $0.2 \mathrm{mg} / \mathrm{mL}$ was the optimal dosage for flocculation activity of single metallic copper nanoparticles. Contrarily, Maliehe et al. [6] reported that $0.8 \mathrm{mg} / \mathrm{mL}$ dosage is optimum for the bioflocculant from which the nanoparticles were synthesized. This improvement is significant for cost effectiveness of the nanoparticles. Less dosage means that less material is required for a flocculation process.

According to Li et al. [21], one of the key factors affecting flocculation process is the $\mathrm{pH}$ of the flocculation mixture. Charge status of the flocculant and surface characteristics of colloidal particles in suspension may be altered by the $\mathrm{pH}$ and consequently affecting their flocculation capabilities [26]. The FeCu nanoparticles effectively flocculate in acidic, neutral, and alkaline conditions as shown in Figure 6. The highest flocculation activity was achieved at neutral $\mathrm{pH}(7)$ with 99\% flocculation activity; however, at acidic $\mathrm{pH}(3)$ and alkaline $\mathrm{pH}(11)$, the flocculation activity was $95 \%$ and there was no statistical significance between the highest flocculation activities suggesting that the nanoparticles are effective in any environment. Both at acidic and alkaline $\mathrm{pH}$ the nanoparticles may have absorbed $\left(\mathrm{H}^{+}\right)$and $\left(\mathrm{OH}^{-}\right)$ions respectively, depending on the functional groups responsible for binding colloids in the nanoparticles. This may have slightly reduced the formation of flocs. Hence, the slightly decreased flocculation activity in this $\mathrm{pH}$. However, the decrease was insignificant [27]. In another study by Jiang et al. [16] indicated that $\mathrm{pH}$ variation is an important factor in the removal efficacy of chromium wastewater by $\mathrm{FeCu}$ bimetallic nanoparticles.

Water is the crucial non-renewable resource on planet earth and is a building block of life in which all biotic components are sustained. Without water, there can be no life. Water should contain no chemicals or radioactive substances that may be harmful to human life and detrimental to the environment. South Africa is an emerging country, developing at fast rates leading to high rates of urbanization and development. High socio-economic development means that there is an increase for water supply and demand with industrial and agricultural sectors using the largest amounts of water from the three sectors, i.e., domestic, agricultural, and industrial sectors. From Figure 7, the effectiveness of $\mathrm{FeCu}$ BNPs was evaluated against three water samples, namely, kaolin, river water, and coal mine. Highest flocculation activity was observed in kaolin clay with $99 \%$ flocculation activity with $85 \%$. Meanwhile, $\mathrm{FeCu}$ BNPs flocculated poorly against river water with just $65 \%$. The poor flocculation activity in river water sample maybe attributed to factors such as ionic strength, water $\mathrm{pH}$, shear, molecular weight, slurry solids, flocculant dilution, 
process conditions, and polymer type, collectively or individually. These factors have great influence on flocculation [28]. These findings suggested that the synthesized material is mostly suitable for industrial flocculation as opposed to domestic river water flocculation.

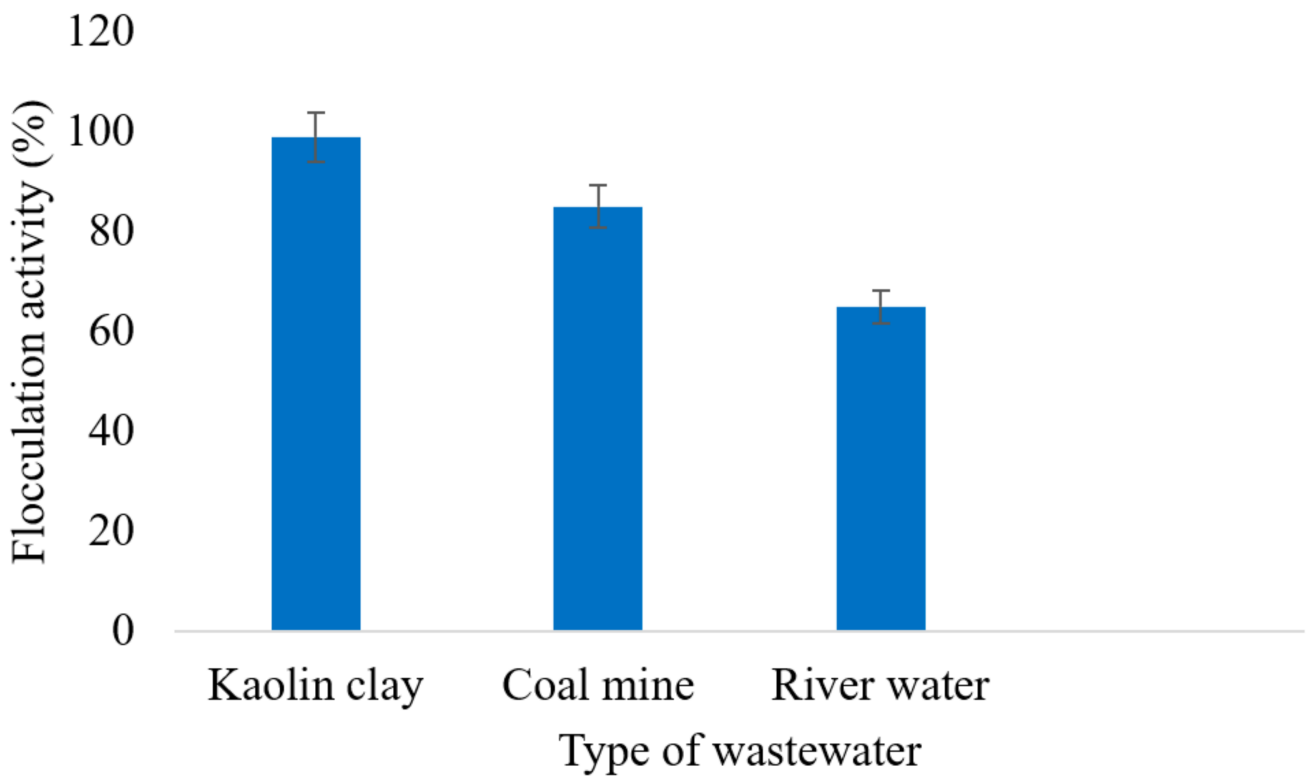

Figure 7. Effectiveness of $\mathrm{FeCu}$ nanoparticles in flocculating different water samples.

Sikosana et al. [29] found that in order to meet the South African regulatory discharge standard of $1 \mathrm{mg} / \mathrm{L}$, that phosphate is one of the substances which wastewater treatment works (WWTW) have to lower. The key factor to prevent eutrophication of surface water is control of phosphorous discharged from industrial and municipal wastewater. One of the major nutrients contributing in the increased eutrophication of lakes and natural waters is phosphorus. Among other problems caused by presence of phosphorous in water is quality water problem, which in turn increases purification costs. Backer [30] found the possible disastrous effect of algal blooms on drinking water (creates dead zones in water, produces toxins that are extremely dangerous to people and animals, raises water treatment costs, and hurts industries that depend on clean water). Chemical precipitation is the current method in use for phosphate removal, which is expensive, and increases the sludge volume by up to $40 \%$ [31]. Forms of phosphorous usually found in aqueous solutions include orthophosphate, which is readily available for biological metabolism without further breakdown. The second form is polyphosphate: molecules with two or more phosphorus atoms, oxygen atoms combined in a complex molecule. Hydrolysis of polyphosphate results to orthophosphate forms and the process is usually quite slow. Usually secondary treatment can only remove 1-2 $\mathrm{mg} / \mathrm{L}$; the excess phosphorous is discharged in the final effluent, causing eutrophication [31]. From Table 2, the FeCu BPNs could remove up to 98\% phosphate from coal mine wastewater.

Due to calcification of downstream processing, a high concentration of soluble calcium in industrial wastewater presents problems [32]. Apart from some bacteria and insects, calcium is a dietary requirement for all organisms. Skeletons and eye lenses of most marine organisms is built from calcium carbonate; meanwhile, terrestrial organisms require calcium phosphate for teeth and bone structure [31]. Calcium is largely responsible for water hardness and may negatively influence toxicity of other compounds. Iron shortage in limed soil may result from iron immobilizing by calcium. Water hardness influence aquatic organisms as a result of its toxicity. The results presented in Table 2 show the removal efficiency for calcium is $87 \%$, which suggests that $\mathrm{FeCu}$ BNPs maybe applicable in coal mine wastewater, which in turn can solve the environmental problems associated with calcium. 
Over the past two decades, sulfate concentration in water has come under increased scrutiny from regulatory authorities. Sulfate has no standard for drinking water or aquatic life in contrast to other pollutants, such as heavy metals, nitrate, and arsenic [33]. The synthesized FeCu BNPs showed some remarkable properties in terms of sulfate removal with $79 \%$ which is much higher than that of single metallic copper nanoparticles in a study conducted by Dlamini et al. [2], where the removal efficiency was $76 \%$. The ability of $\mathrm{FeCu}$ BNPs to remove both suspended solids (colloids) and dissolved solids in the tested parameters may be attributed to surface morphology and functional groups present in the synthesized material [6,34].

Two simple parameters such as COD and BOD can be used to measure various compounds of organic matter containing materials. BOD is a standard test for assessing the oxygen-demand concentration of microbes to degrade organic matter over a given time period, usually five days. Meanwhile, COD is a standard test for water to consume oxygen in the form of potassium dichromate during the degradation of organic matter and inorganic chemicals such as ammonia and nitrite for a few hours [35]. Non-biodegradable organic matter in the influent that may be inefficiently degraded by the biological effluent treatment processes is indicated by high concentrations of BOD: COD ratios [36]. As demonstrated in Table 2, the FeCu BNPs was used to treat coal mine wastewater with an initial COD concentration of $1557 \mathrm{mg} / \mathrm{L}$. After the treatment, the final COD concentration dropped to $124.56 \mathrm{mg} / \mathrm{L}$, and the COD removal rate was $92 \%$. Meanwhile, the initial BOD concentration was $123.2 \mathrm{mg} / \mathrm{L}$ and drop to $3.41 \mathrm{mg} / \mathrm{L}$, which is equivalent to $97 \%$ removal efficiency. Therefore, the FeCu BNPs could be used for the removal of COD and BOD from coal mine wastewater. The results are comparable with those of Ma and Zhang [37], where it was reported that bimetallic zero-valent iron could remove up to $85 \%$ and $96.7 \%$ COD and BOD, respectively, from wastewater. Furthermore, the bioflocculant from which the nanoparticles were synthesized was less active on BOD and COD removal. It could only remove up to $59 \%$ and $72 \%$ BOD and COD, respectively. These findings suggest that nanoparticles are more efficient compared to the bioflocculant. Therefore, it can be deduced that the synthesized material is cost effective [6].

\section{Conclusions}

In this research, characterization and application of $\mathrm{FeCu}$ BNPs synthesized from a bioflocculant were conducted. Results show hydroxyl group $(-\mathrm{O}-\mathrm{H})$ and amine group $\left(-\mathrm{NH}_{2}\right)$ were some of the functional groups revealed by FT-IR and the bioflocculant formed a chain-like aggregation that are evident from TEM results, attributed to the magnetic attractive force. Meanwhile, SEM analysis revealed irregular FeCu BNPs and a crystalline bioflocculant. This suggested that the bimetallic nanoparticles were formed as the bioflocculant was modified morphologically. The nanoparticles flocculate effectively at low dosage $(0.2 \mathrm{mg} / \mathrm{mL})$. The highest flocculation activity was achieved at neutral $\mathrm{pH}(7)$ with 99\% flocculation activity; however, at acidic $\mathrm{pH}$ (3) and alkaline $\mathrm{pH}$ (11) conditions, the flocculation activity was $95 \%$ and there was no statistical significance between the highest flocculation activities suggesting that the nanoparticles are effective in acidic, neutral, and alkaline $\mathrm{pH}$. The synthesized material flocculated effectively in kaolin clay and coal mine wastewater with $99 \%$ and $85 \%$ flocculation activity, respectively. Furthermore, the synthesized material proved to be effective on removing COD and BOD with 92 and 97\%, respectively, and has high phosphate removal with $98 \%$ efficacy. Lastly, the mechanism of action in pollutant removal should be further investigated for the synthesized material.

Author Contributions: Conceptualization, A.K.B. and V.S.R.P.; formal analysis, N.G.D. and V.S.R.P.; investigation, N.G.D.; supervision, A.K.B. and V.S.R.P.; writing—original draft, N.G.D.; writing—review and editing, V.S.R.P. All authors have read and agreed to the published version of the manuscript.

Funding: Rajasekhar Pullabhotla would like to acknowledge the National Research Foundation (NRF, South Arica) for the financial support in the form of the Incentive Fund Grant (Grant No: 103691) and Research Developmental Grant for Rated Researchers (112145). 
Institutional Review Board Statement: Not applicable.

Informed Consent Statement: Not applicable.

Data Availability Statement: Data sharing not applicable

Acknowledgments: Nkosinathi Dlamini would like to acknowledge the Council for Scientific and Industrial Research (CSIR, South Africa) for the financial assistance in the form of the Doctoral bursary. The authors would like to acknowledge the Electron Microscopy Unit at the University of KwaZulu-Natal, Westville campus, for providing support by letting us use the TEM and SEM-EDX facilities for the characterization of nanomaterials. The authors would like to thank Tendele coal mine for supplying us with wastewater samples.

Conflicts of Interest: The authors declare that there is no conflict of interest.

\section{References}

1. Kefeni, K.K.; Msagati, T.A.; Nkambule, T.T.; Mamba, B.B. Synthesis and application of hematite nanoparticles for acid mine drainage treatment. J. Environ. Chem. Eng. 2018, 6, 1865-1874. [CrossRef]

2. Dlamini, N.G.; Basson, A.K.; Rajasekhar Pullabhotla, V.S. Biosynthesis of bioflocculant passivated copper nanoparticles, characterization and application. Phys. Chem. Earth Parts ABC 2020, 102898. [CrossRef]

3. Akapo, C.S.O.; Ntombela, Z.G.; Pullabhotla, V.S.R.; Basson, A.K. Isolation, optimization, characterization and application of bioflocculant BA-CGB produced by novel Bacillus atrophaeus isolated from Richards Bay Harbour, South Africa. Biosci. Res. 2019, 16, 3873-3902.

4. Okaiyeto, K.; Nwodo, U.U.; Okoli, S.A.; Mabinya, L.V.; Okoh, A.I. Implications for public health demands alternatives to inorganic and synthetic flocculants: Bioflocculants as important candidates. Microbiol. Open 2016, 5, 177-211. [CrossRef] [PubMed]

5. Ngema, S.; Basson, A.; Maliehe, T. Synthesis, characterization and application of polyacrylamide grafted bioflocculant. Phys. Chem. Earth Parts ABC 2020, 115, 102821. [CrossRef]

6. Maliehe, T.S.; Basson, A.K.; Dlamini, N.G. Removal of pollutants in mine wastewater by a non-cytotoxic polymeric bioflocculant from alcaligenes faecalis HCB2. Int. J. Environ. Res. Public Health 2019, 16, 4001. [CrossRef]

7. Zhang, Z.Q.; Lin, B.; Xia, S.Q.; Wang, X.J.; Yang, A.M. Production and application of a novel bioflocculant by multiplemicroorganism consortia using brewery wastewater as carbon source. J. Environ. Sci. 2007, 19, 667-673. [CrossRef]

8. Guo, H.; Hong, C.; Zhang, C.; Zheng, B.; Jiang, D.; Qin, W. Bioflocculants' production from a cellulase-free xylanase-producing Pseudomonas boreopolis G22 by degrading biomass and its application in cost-effective harvest of microalgae. Biores. Technol. 2018, 255, 171-179. [CrossRef]

9. Mohammed, J.N.; Wan Dagang, W.R.Z. Implications for industrial application of bioflocculant demand alternatives to conventional media: Waste as a substitute. Water Sci. Technol. 2019, 80, 1807-1822. [CrossRef]

10. Fakhri, A.; Tahami, S.; Naji, M. Synthesis and characterization of core-shell bimetallic nanoparticles for synergistic antimicrobial effect studies in combination with doxycycline on burn specific pathogens. J. Photochem. Photobiol. B Biol. 2017, 169, 21-26. [CrossRef]

11. Sharma, G.; Kumar, D.; Kumar, A.; Ala'a, H.; Pathania, D.; Naushad, M.; Mola, G.T. Revolution from monometallic to trimetallic nanoparticle composites, various synthesis methods and their applications: A review. Mater. Sci. Eng. C 2017, 71, 1216-1230. [CrossRef] [PubMed]

12. Sharma, G.; Kumar, A.; Sharma, S.; Naushad, M.; Dwivedi, R.P.; ALOthman, Z.A.; Mola, G.T. Novel development of nanoparticles to bimetallic nanoparticles and their composites: A review. J. King Saud Univ. Sci. 2019, 31, 257-269. [CrossRef]

13. Lu, H.; Wang, J.; Stoller, M.; Wang, T.; Bao, Y.; Hao, H. An overview of nanomaterials for water and wastewater treatment. Adv. Mater. Sci. Eng. 2016, 2016. [CrossRef]

14. Esakkimuthu, T.; Sivakumar, D.; Akila, S. Application of nanoparticles in wastewater treatment. Pollut. Res 2014, 33, 567-571.

15. Dlamini, N.G.; Basson, A.K.; Pullabhotla, V.S.R. Optimization and application of bioflocculant passivated copper nanoparticles in the wastewater treatment. Int. J. Environ. Res. Public Health 2019, 16, 2185. [CrossRef]

16. El-Shall, M.S.; Abdelsayed, V.; Abd El Rahman, S.K.; Hassan, H.M.; El-Kaderi, H.M.; Reich, T.E. Metallic and bimetallic nanocatalysts incorporated into highly porous coordination polymer MIL-101. J. Mater. Chem. 2009, 19, 7625-7631. [CrossRef]

17. Zhao, H.; Zhong, C.; Chen, H.; Yao, J.; Tan, L.; Zhang, Y.; Zhou, J. Production of bioflocculants prepared from formaldehyde wastewater for the potential removal of arsenic. J. Environ. Manag. 2016, 172, 71-76. [CrossRef]

18. Dlamini, N.G.; Basson, A.K.; Pullabhotla, V.S.R. A Comparative study between Bimetallic Iron@ copper nanoparticles with iron and copper nanoparticles synthesized Using a bioflocculant: Their applications and biosafety. Processes 2020, 8, 1125. [CrossRef]

19. Kurane, R.; Toeda, K.; Takeda, K.; Suzuki, T. Culture conditions for production of microbial flocculant by Rhodococcus erythropolis. Agricult. Biol. Chem. 1986, 50, 2309-2313.

20. Mata, Y.; Torres, E.; Blazquez, M.; Ballester, A.; González, F.; Munoz, J. Gold (III) biosorption and bioreduction with the brown alga Fucus vesiculosus. J. Hazard. Mater. 2009, 166, 612-618. [CrossRef] 
21. Jiang, D.; Huang, D.; Lai, C.; Xu, P.; Zeng, G.; Wan, J.; Tang, L.; Dong, H.; Huang, B.; Hu, T. Difunctional chitosan-stabilized Fe/Cu bimetallic nanoparticles for removal of hexavalent chromium wastewater. Sci. Total Environ. 2018, 644, 1181-1189. [CrossRef] [PubMed]

22. Lu, Z.-H.; Li, J.; Zhu, A.; Yao, Q.; Huang, W.; Zhou, R.; Zhou, R.; Chen, X. Catalytic hydrolysis of ammonia borane via magnetically recyclable copper iron nanoparticles for chemical hydrogen storage. Int. J. Hydrog. Energy 2013, 38, 5330-5337. [CrossRef]

23. Lazarides, A.A.; Schatz, G.C. DNA-linked metal nanosphere materials: Structural basis for the optical properties. J. Phys. Chem. B 2000, 104, 460-467. [CrossRef]

24. Wang, L.; Ma, F.; Qu, Y.; Sun, D.; Li, A.; Guo, J.; Yu, B. Characterization of a compound bioflocculant produced by mixed culture of Rhizobium radiobacter F2 and Bacillus sphaeicus F6. World J. Microbiol. Biotechnol. 2011, 27, 2559-2565. [CrossRef]

25. Zulkeflee, Z.; Aris, A.Z.; Shamsuddin, Z.H.; Yusoff, M.K. Cation dependence, pH tolerance, and dosage requirement of a bioflocculant produced by Bacillus spp. UPMB13: Flocculation performance optimization through kaolin assays. Sci. World J. 2012, 2012. [CrossRef]

26. Li, X.-M.; Yang, Q.; Huang, K.; Zeng, G.-M.; Liao, D.-X.; Liu, J.-J.; Long, W.-F. Screening and characterization of a bioflocculant produced by Aeromonas sp. Biomed. Environ. Sci. BES 2007, 20, 274-278.

27. Lin, J.; Harichund, C. Isolation and characterization of heavy metal removing bacterial bioflocculants. Afr. J. Microbiol. Res. 2011, 5, 599-607.

28. Pillai, J. Flocculants and coagulants: The keys to water and waste management in aggregate production. In Condensed Version Appeared in December Issue of Stone Review; Nalco Company: Budapest, Hungary, 1997.

29. Sikosana, M.K.; Randall, D.G.; von Blottnitz, H. A technological and economic exploration of phosphate recovery from centralised sewage treatment in a transitioning economy context. Water SA 2017, 43, 343-353. [CrossRef]

30. Backer, L.C. Cyanobacterial harmful algal blooms (CyanoHABs): Developing a public health response. Lake Reserv. Manag. 2002, 18, 20-31. [CrossRef]

31. LENNTECH. Phosphorus Removal from Wastewater. PRW 2004/05. 2005.

32. Hammes, F.; Seka, A.; Van Hege, K.; Van de Wiele, T.; Vanderdeelen, J.; Siciliano, S.D.; Verstraete, W. Calcium removal from industrial wastewater by bio-catalytic $\mathrm{CaCO} 3$ precipitation. J. Chem. Technol. Biotechnol. Int. Res. Process. Environ. Clean Technol. 2003, 78, 670-677. [CrossRef]

33. Ramachandran, V. Removal, control and management of total dissolved solids from process effluent streams in the non-ferrous metallurgical industry-A review. In Proceedings of the C.Q. Jia, V. Ramachandran et al. the of Water, Air and Land: Sustainability Issues in Mineral and Metal Extraction (WALSIM II) Symposium, 51st Annual Conference of Metallurgists, Niagara Falls, ON, Canada, 30 September-3 October 2012; pp. 101-117.

34. Singh, R.P.; Karmakar, G.; Rath, S.; Karmakar, N.; Pandey, S.; Tripathy, T.; Panda, J.; Kanan, K.; Jain, S.; Lan, N. Biodegradable drag reducing agents and flocculants based on polysaccharides: Materials and applications. Polym. Eng. Sci. 2000, 40, 46-60. [CrossRef]

35. Samudro, G.; Mangkoedihardjo, S. Review on bod, cod and bod/cod ratio: A triangle zone for toxic, biodegradable and stable levels. Int. J. Acad. Res. 2010, 2, 235-239.

36. Iloms, E.; Ololade, O.O.; Ogola, H.J.; Selvarajan, R. Investigating industrial effluent impact on municipal wastewater treatment plant in Vaal, South Africa. Int. J. Environ. Res. Public Health 2020, 17, 1096. [CrossRef] [PubMed]

37. Ma, L.; Zhang, W.-X. Enhanced Biological Treatment of Industrial Wastewater with Bimetallic Zero-Valent Iron; ACS Publications: Washington, DC, USA, 2008. 